Article

\title{
On the Effect of Heat Treatments on the Adhesion, Finishing and Decay Resistance of Japanese cedar (Cryptomeria japonica D. Don) and Formosa acacia (Acacia confuse Merr.(Leguminosae))
}

\author{
Chia-Wei Chang ${ }^{1} \mathbb{(}$, Wei-Ling Kuo ${ }^{2}$ and Kun-Tsung Lu ${ }^{1, *}$ \\ 1 Department of Forestry, National Chung Hsing University, Taichung 402, Taiwan \\ 2 Forestry Bureau, Council of Agriculture, Executive Yuan, Taichung 402, Taiwan \\ * Correspondence: lukt@dragon.nchu.edu.com; Tel.: +886-4-22840345 (ext. 122)
}

Received: 14 June 2019; Accepted: 11 July 2019; Published: 13 July 2019

check for updates

\begin{abstract}
In Taiwan, it is important to maintain sustainable development of the forestry industry in order to raise the self-sufficiency of domestic timber. Japanese cedar (Cryptomeria D. Don and Formosa acacia (Acacia confusa Merr.(Leguminosae)) have abundant storage options and are the potential candidates for this purpose. Heat treatment is a new environment-friendly method used to enhance the dimensional stability and durability of wood. On treatment, a surface with new characteristics is produced because of wood component changes. Consequently, an inactivated surface and a weak boundary layer are generated, and the wettability for adhesives and coatings is reduced. Furthermore, it decreases the $\mathrm{pH}$ value of the wood surface, and results in delay or acceleration during the curing of adhesives. This phenomenon must be paid attention to for practical applications of heat-treated wood. Ideal heat-treated conditions of $C$. japonica and $A$. confusa woods with productive parameters such as temperature, holding time, heating rate, and thicknesses of wood were identified in our previous study. In this research work, we focus on the normal shear strength of heat-treated wood with adhesives such as urea-formaldehyde resin (UF) and polyvinyl acetate (PVAc), and the finishing performances of heat-treated wood with polyurethane (PU) and nitrocellulose lacquer (NC) coatings as well as assessing the decay-resistance of heat-treated wood. The results show that heat-treated wood had a better decay resistance than untreated wood. The mass decrease of heat-treated wood was only $1 / 3$ or even less than the untreated wood. The normal shear strength of heat-treated wood with UF and PVAc decreased from $99 \%$ to $72 \%$ compared to the untreated wood, but the wood failure of heat-treated wood was higher than that of the untreated one. Furthermore, the adhesion and impact resistance of wood finished by PU and NC coatings showed no difference between the heat-treated wood and untreated wood. The finished heat-treated wood had a superior durability and better gloss retention and lightfastness than that of the untreated wood.
\end{abstract}

Keywords: heat-treated wood; decay resistance; adhesion; finishing

\section{Introduction}

Wood is an excellent and environment-friendly renewable material, which possesses good mechanical strength, low thermal expansion, aesthetic appeal and is easy to process for a variety of applications. Owing to these characteristics and its abundance, wood has been used for building, structure, furniture, and other objects that meet the demands of people in the modern world. However, being a biological material, it is susceptible to warping, splitting, photodegradation and biodeterioration, highlighting natural anisotropic and hygroscopic characteristics. These defects restrict its use in certain applications. It is thus necessary to enhance its dimensional stability and 
durability to expand applications of the material. Wood treatments include chemical modification methods such as esterification and etherification [1,2] and using chromated copper arsenate (CCA) or alkaline copper quaternary ammonium compounds (ACQ) preservatives [3-5], which, however, cause environment concerns.

A new environment-friendly method used to enhance the dimensional stability and durability of wood is heat treatment. This technique is suitable for wood due to its non-toxic characteristics. In heat-treated wood, physical and chemical properties such as density, equilibrium moisture content, roughness, and strength are altered by submitting wood to high temperatures $\left(150-230{ }^{\circ} \mathrm{C}\right)$ in an inert or restricted air environment. The dimensional characteristics and decay resistance of wood can be improved and the treatment results in a uniform dark color. However, its strength is decreased as compared to those of untreated control samples. The use of heat treatment as a wood modification method and its products have increased significantly over the last decade and have been well studied [6-15]. However, in practical utilization, the adhesion, finishing, and decay resistance performances of heat-treated wood have not been examined enough.

After heat treatment, new surface characteristics are produced because of wood component changes. The results affect the wettability of heat-treated wood and further affect its bonding strength $[11,12,16]$. In addition, the hydrophobic extractives and volatile organic compounds that are derived from the depolymerization of wood components, especially from hemi-cellulose [17], moved to or deposited on the wood surface. As a result, an inactivated wood surface and a weak boundary layer were produced. Consequently, the wettability of wood for adhesives and coatings [18-21] was reduced. Furthermore, it decreases the $\mathrm{pH}$ value of wood surface and results in delay or acceleration during the curing of adhesives [18,22]. This phenomenon must be paid attention to for practical applications of heat-treated wood.

In Taiwan, the domestic timber yield accounts for merely $0.5 \%$ of its timber consumption, which implicates that raw timber materials are almost completely imported. In view of this, relevant policies-such as enlarging planting area and increasing the utilization of domestic woods-should be formulated to raise the self-sufficiency of domestic timber, which is vital for Taiwan to maintain sustainable development of its forestry industry. Japanese cedar (Cryptomeria japonica D. Don), a softwood, and Formosa acacia (Acacia confuse Merr.(Leguminosae)), a hardwood, have abundant storage options and are potential candidates for this purpose. The total cultivation area of $C$. japonica in Taiwan is 39,100 ha (or $2.68 \%$ ) and of $A$. confusa is 21,200 ha (or $1.43 \%$ ) [23]. C. japonica and A. confusa woods be used for making furniture, building, structures and other objects.

In our previous study, the heat treatments of $C$. japonica and $A$. confusa woods with moisture content of $12 \%$ were performed using a steel kiln under an $\mathrm{N}_{2}$ atmosphere. The parameters of heat-treated conditions such as temperature (130, 160,190, 220, 250 and $\left.280{ }^{\circ} \mathrm{C}\right)$, holding times $(1,2$ and $3 \mathrm{~h})$, thicknesses $(30,50$ and $70 \mathrm{~mm})$ and heating rates $\left(10,20\right.$ and $\left.30{ }^{\circ} \mathrm{C} / \mathrm{h}\right)$ were examined for the best performances of heat-treated woods. The results indicated that the best heat-treated conditions for the superior of dimensional stability, hardness and static bending strength of woods included heating rates of $10^{\circ} \mathrm{C} / \mathrm{h}$, temperature of $190^{\circ} \mathrm{C}$, wood thickness of $50 \mathrm{~mm}$, and holding time of $2 \mathrm{~h}$ for C. japonica and $3 \mathrm{~h}$ for $A$. confusa [24]. Furthermore, for practical utilization, in this report, we focus on the normal shear strength of heated C. japonica and A. confusa woods with urea-formaldehyde resin (UF) and polyvinyl acetate (PVAc) wood adhesives, the performances of finishing properties of woods with polyurethane (PU) and nitrocellulose lacquer (NC) wood coatings, and decay-resistance of woods by soil block test.

\section{Materials and Methods}

20-30-year-old A. confusa and C. japonica woods were obtained from Hui-Sun Forest Station of the Experimental Forest of National Chung Hsing University in Nan-Tou County, Taiwan. The wood was cut into the desired dimensions after air-drying and then conditioned for one week at $20{ }^{\circ} \mathrm{C}$ and $65 \%$ relative humidity. The adhesives, including urea-formaldehyde resin (UF) with a solid content of $65 \%$, 
was purchased from Wood Glue Industrial Co., Ltd., Tainan, Taiwan. Polyvinyl acetate (PVAc) was supplied by Nan Pao Resins Chemical Co., Ltd., Tainan, Taiwan. The coatings, including two-package polyurethane resin (PU) and nitrocellulose lacquer (NC), were purchased from Yan Chang Trading Co., Ltd., Taichung, Taiwan.

\subsection{Heated Treatment of Wood}

A. confusa and C. japonica with dimensions of $50 \mathrm{~mm}(\mathrm{~T}) \times 50 \mathrm{~mm}(\mathrm{R}) \times 330 \mathrm{~mm}(\mathrm{~L})$ and moisture content of $12 \%$ were placed in a stainless steel cylindrical equipment (390 mm diameter and $800 \mathrm{~mm}$ height), as shown in Figure 1 . The autoclave body was flushed with a continuous $\mathrm{N}_{2}$ gas flow first with a flowing rate of $500 \mathrm{~mL} / \mathrm{min}$ for $30 \mathrm{~min}$ and then the flowing rate was adjusted to $50 \mathrm{~mL} / \mathrm{min}$ for the heated procedure. The temperature was first heated from room temperature to $100{ }^{\circ} \mathrm{C}$ at a heating rate of $10^{\circ} \mathrm{C} / \mathrm{min}$ and holding time of $6 \mathrm{~h}$ and then heated to $190^{\circ} \mathrm{C}$ under the same heating rate and holding time of $2 \mathrm{~h}$ for $C$. japonica wood and $3 \mathrm{~h}$ for $A$. confusa wood. After the heated treatment, the wood samples were cooled to room temperature and conditioned for one week at $20{ }^{\circ} \mathrm{C}$ and $65 \%$ relative humidity. The moisture content, density, environmental moisture content (at $40{ }^{\circ} \mathrm{C}$, a relative humidity of $65 \%$ ), contact angle of radial section, modulus of rupture were measured in our previous study [24], and the results were $2.6 \%, 387 \mathrm{~kg} / \mathrm{m}^{3}, 2.7 \%, 23.4 \%, 57.2 \mathrm{MPa}$ for C. japonica heat-treated wood, and $2.6 \%, 684 \mathrm{~kg} / \mathrm{m}^{3}, 5.4 \%, 37.8 \%, 44.4 \mathrm{MPa}$ for $A$. confusa heat-treated wood.

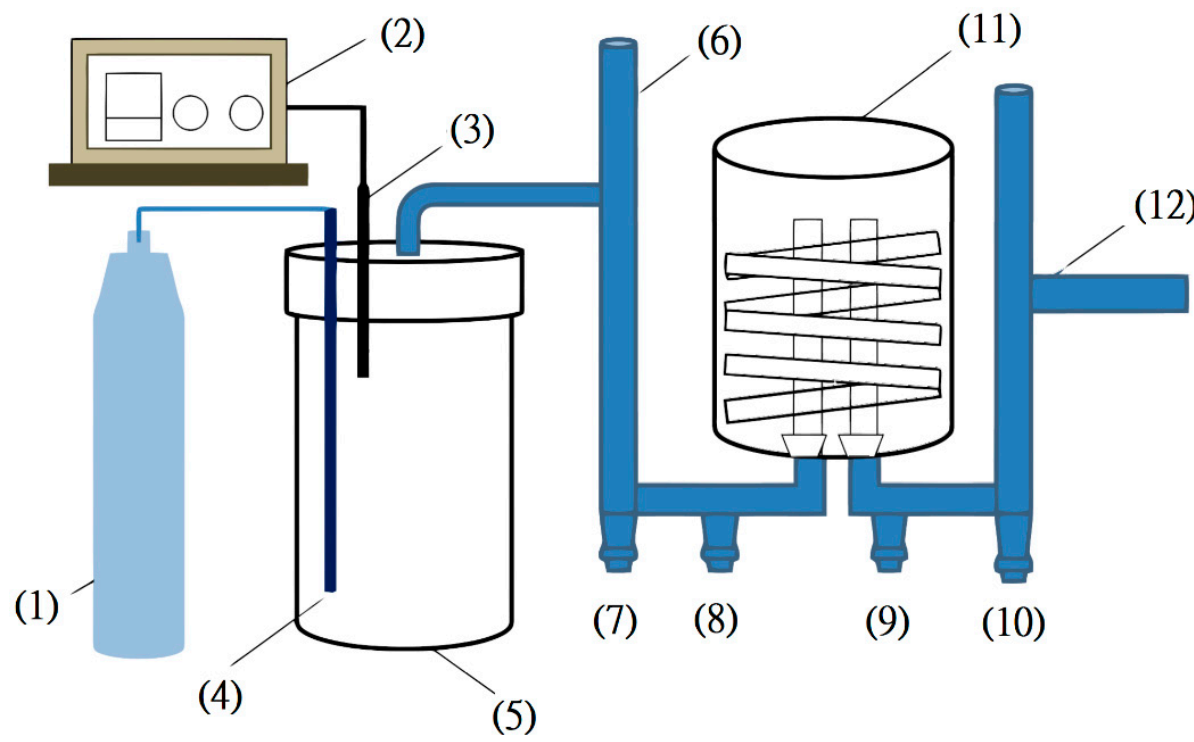

Figure 1. Schematic diagram of the heat-treated equipment. (1) $\mathrm{N}_{2}$ cylinder, (2) Controller, (3) Thermocouple, (4) Air supply tube, (5) Heat-treated body, (6) Condenser, (7 10) Liquid-collecting vessels, (11) Water cooling tower, (12) Exhauster.

\subsection{Compression Shear Bonding Strength of Heat-Treated Wood}

The shear bonding strength of heat-treated wood specimens were measured by compression loading in accordance with Chinese National Standards (CNS) 5809. The heat-treated and untreated woods were cut into thickness of $10 \mathrm{~mm}$ specimens and the out-layer with radial section of the heat-treated wood was as a glue surface. The UF resin (with adding $1 \% \mathrm{NH}_{4} \mathrm{Cl}$ as a catalyst) and PVAc were applied on both sides of the interface $\left(200 \mathrm{~g} / \mathrm{m}^{2}\right.$ for each layer $)$, respectively. The specimens were pressed by compression molding machine at room temperature and pressure of $1.47 \mathrm{MPa}$ for $48 \mathrm{~h}$. After conditioning at room temperature for $48 \mathrm{~h}$, the glued samples were cut into $30 \mathrm{~mm}(\mathrm{~L}) \times 25 \mathrm{~mm}$ $(\mathrm{R}) \times 20 \mathrm{~mm}(\mathrm{~T})$ as shown in Figure 2. Normal shear strength test of the specimens was conducted with a Universal Testing Machine (Shimadzu UEH-10, SHIMADZU Co., Kyoto, Japan) at a crosshead speed of $1 \mathrm{~mm} / \mathrm{min}$ with duplicates of 10, and wood failure was noted. 


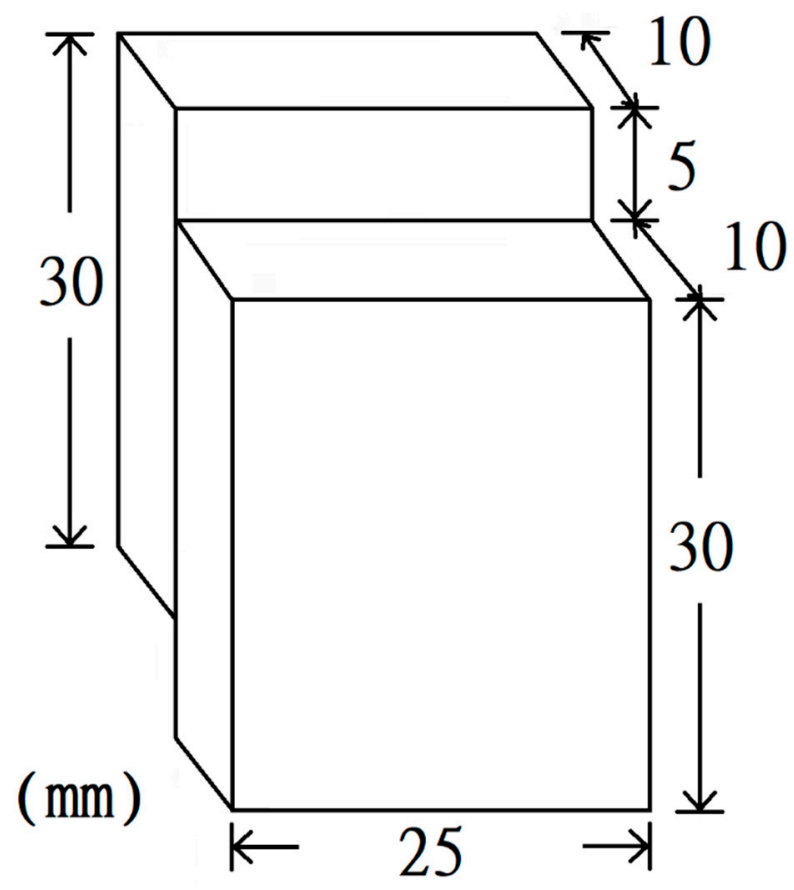

Figure 2. Dimension of testing sample for the compression shear bonding strength test.

\subsection{Heat-Treated Wood Finishing and Characterization of Finishing Performances}

The specimens for wood finishing were quarter-sawed, and had a dimension around $15 \mathrm{~cm}$ $(\mathrm{L}) \times 10 \mathrm{~cm}(\mathrm{R}) \times 1.5 \mathrm{~cm}(\mathrm{~T})$. The viscosity of 2-package PU coating (polyol mixed with aliphatic isocyanate hardener by wt. of 1:1) and NC lacquer were adjusted to $20 \mathrm{~s}$ with thinner using No. 4 Ford cup at room temperature. The two coatings were finished on the heat-treated and untreated woods, respectively, by using an air spray gun with the proper ratio of compressed air and fluid coatings to obtain a smooth pattern of spay flow, and thickness of films. The thickness of the dry film on the wood specimens surface were $100 \mu \mathrm{m}$ and $60 \mu \mathrm{m}$ for the PU coating and NC lacquer, respectively. The finished specimens were then reconditioned at room temperature for 1 week prior to examination of the properties of the films.

The adhesion of tested films was determined by the cross-cut method according to CNS K 6800 with duplicates of 3 ; the best adhesion was 10 grade followed by $8,6,4,2$ and 0 grade. The impact resistance of the films was determined based on the striking height of the finished wood panels that do not crack on a knowing falling weight of $300 \mathrm{~g}$ and impact hammer diameter of $1 / 2$ inch by using a Dupont Impact Tester IM-601 (DU PONT Co., Wilmington, DE, USA) according to American Society for Testing and Materials (ASTM) D5420. The gloss of films finished on wood and parallel to grain was detected by using Dr. Lange Reflectometer $60^{\circ}$ Gloss Meter (DR LANGE Co., Dusseldorf, Germany) according to Deutsches Institut für Normung \& International Organization for Standardization (DIN ISO) 4630 with duplicates of 10 . The durability of films was evaluated using hot and cold cycling tests, in which one tested cycle of the specimens were first placed them into $-20^{\circ} \mathrm{C}$ refrigerator for $2 \mathrm{~h}$, and then transferred to $50{ }^{\circ} \mathrm{C}$ oven for another $2 \mathrm{~h}$ according to CNS15200-7-4. The cycle number was recorded if the sample film cracked. If the films were intact after the cycling test, gloss retention of film was measured.

The lightfastness of films finished on wood was carried out with a Paint Coating Fade Meter (SUGA TEST INSTRUMENTS Co., Tokyo, Japan), the light source was mercury light (H400-F) and chamber temperature was at $32 \pm 4{ }^{\circ} \mathrm{C}$. After $100 \mathrm{~h}$ exposure, the changes in color of the specimens were measured with nine points on the radial section using a spectrophotometer (CM-3600d, Minolta. Osaka, Japan) fitted with a D65 light source with a measuring angle of $10^{\circ}$ and a test-window diameter of $8 \mathrm{~mm}$. The tristimulus values $\mathrm{X}, \mathrm{Y}$, and $\mathrm{Z}$ of all specimens were obtained directly from the colormeter. 
The brightness $\left(L^{*}\right)$, redness-greenness $\left(a^{*}\right)$, and yellowness-blueness $\left(b^{*}\right)$ color parameters were then computed according to the Commission internationale de l'éclairage (CIE) $1976 \mathrm{~L}^{*} \mathrm{a}^{*} \mathrm{~b}^{*}$ color system, followed by calculating the brightness difference $\left(\Delta L^{*}\right)$, color difference $\left(\Delta E^{*}\right)$ and yellowness difference ( $\triangle$ YI, calculated by ASTM E313) directly from the Minolta Managed Content Services (MCS) software system (version of 3.1, Newport Beach, CA, USA).

\subsection{Soil Block Test for Decay Resistance of Heat-Treated Woods}

The soil block test was performed, with partial reference to the AWPA E14-94 standard. The samples were cut into a size of $200 \mathrm{~mm}(\mathrm{~L}) \times 20 \mathrm{~mm}(\mathrm{R}) \times 20 \mathrm{~mm}(\mathrm{~T})$ with duplicates of 5 . The test samples were buried upright with $200 \mathrm{~mm}$ length of the samples in the ground and each sample was installed $50 \mathrm{~mm}$ apart. The testing site was located in National Chung Hsing University, Taichung, Taiwan. The surface layer ca. $100 \mathrm{~mm}$ of the soil is humus and underlayer is yellow-brown color soil. The experiment was performed for 50 days and the weight loss, brightness difference $\left(\Delta L^{*}\right)$ and color difference $\left(\Delta E^{*}\right)$ of the test samples were assessed.

\section{Results and Discussion}

\subsection{The Normal Shear Strength}

The normal shear strength of heat-treated and untreated C. japonica and A. confusa wood with UF and PVAc adhesives are listed in Table 1. For UF adhesive, the shear strength of heat-treated C. japonica and $A$. confusa woods were 7.66 and $13.98 \mathrm{MPa}$, respectively, slightly lower than those of untreated woods at 7.73 and $19.50 \mathrm{MPa}$, respectively. The results may be due to preferential degradation of the less-ordered molecules of amorphous cellulose and hemi-cellulose with heat-treatment, and the increase of the crystallinity of cellulose as well as the affecting of wettability of UF adhesive on the heat-treated wood surface $[13,25]$. It also may be caused by the extractives of wood migrating to the surface with higher temperature heat treatment, which affected the wettability of the UF adhesive $[20,26,27]$. In addition, the decomposition products during the heat-treated processing (such as acidic components including acetic acid and formic acid) decrease the $\mathrm{pH}$ value on the wood surface, which accelerate the curing of the UF adhesive and further reduce the gluing ability of wood $[20,28]$. The wood failure of heat-treated C. japonica was $90 \%$ and was higher than the untreated one at $40 \%$. The appearance of wood failure occurred in the wood itself and not in the interface of the glue layer, as shown in Figure 3. This result was due to the degradation of hemi-cellulose and cellulose of wood during the heat-treated processing and the decrease of the hardness as well as the brittle surface of heat-treated wood [29,30]. Similar results were also obtained for heat-treated $A$. confusa wood with wood failure of $100 \%$ and untreated wood of $80 \%$.

Table 1. Normal shear strength of untreated and treated Japanese cedar (Cryptomeria japonica D. Don) and Formosa acacia (Acacia confuse Merr.(Leguminosae)) wood with urea-formaldehyde resin (UF) and polyvinyl acetate (PVAc) adhesives.

\begin{tabular}{cccc}
\hline \multirow{2}{*}{ Wood } & \multicolumn{2}{c}{ Shear Strength (MPa) } \\
\cline { 3 - 4 } & & UF & PVAc \\
\hline \multirow{2}{*}{ C. japonica } & Untreated & $7.73 \pm 0.35(40)^{2}$ & $8.25 \pm 0.30(90)$ \\
\cline { 2 - 4 } & Heat-treated $^{2}$ & $7.66 \pm 0.33(90)$ & $7.43 \pm 0.33(100)$ \\
\hline \multirow{2}{*}{ A. confusa } & Untreated $^{2}$ & $19.50 \pm 0.22(80)$ & $15.39 \pm 0.31(20)$ \\
\cline { 2 - 4 } & Heat-treated & $13.98 \pm 0.30(100)$ & $11.39 \pm 1.05(40)$ \\
\hline
\end{tabular}

${ }^{1}$ Heat-treated conditions are heating rates of $10{ }^{\circ} \mathrm{C} / \mathrm{h}$, temperature of $190{ }^{\circ} \mathrm{C}$, wood thickness of $50 \mathrm{~mm}$, and holding time of $2 \mathrm{~h}$ for $C$. japonica and $3 \mathrm{~h}$ for $A$. confusa. ${ }^{2}$ represents wood failure (\%). 


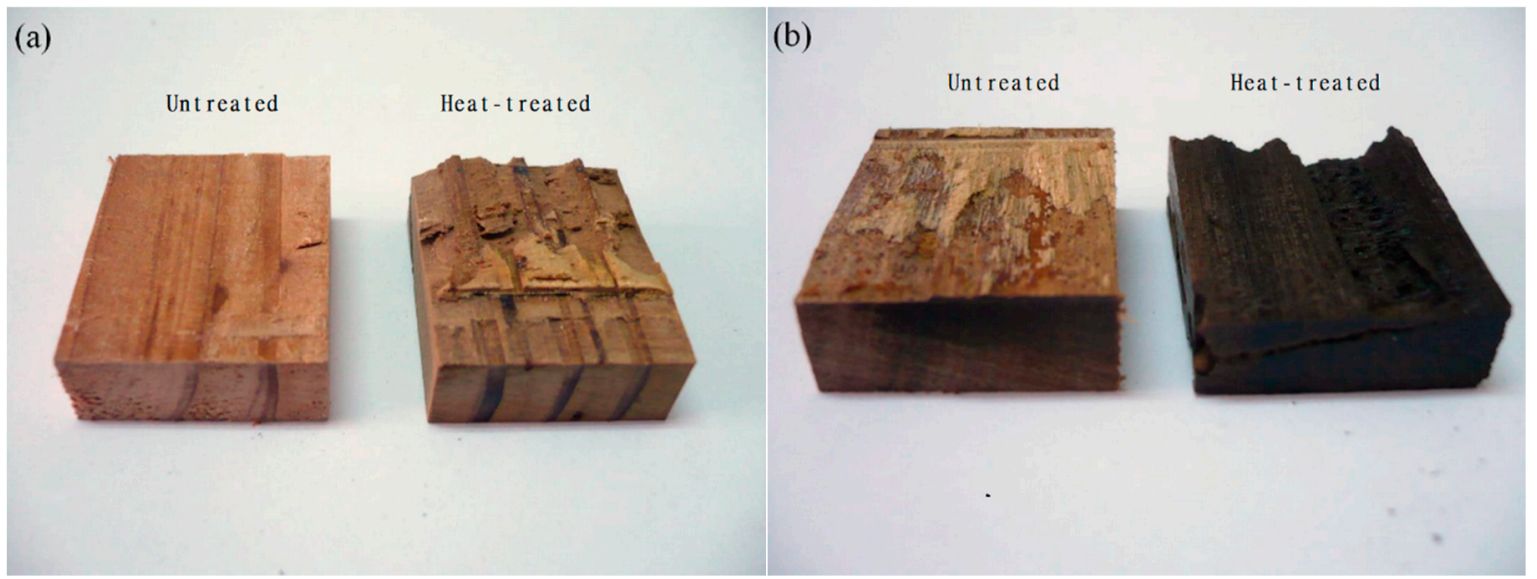

Figure 3. Appearance of untreated and heat-treated Japanese cedar (Cryptomeria japonica D. Don) (a) and Formosa acacia (Acacia confuse Merr.(Leguminosae)) (b) wood with urea-formaldehyde resin (UF) adhesive after the shear strength test.

For the PVAc adhesive, the similar results of adhesion performances were as the UF adhesive. The shear strength of heat-treated C. japonica and A. confusa wood was 7.43 and $11.39 \mathrm{MPa}$, which was lower than that of untreated wood at 8.25 and $15.39 \mathrm{MPa}$, respectively. However, the wood failure of heat-treated C. japonica and A. confusa wood was 100 and $40 \%$ and was higher than that of untreated ones at 90 and $20 \%$, respectively. The appearances of untreated and heat-treated C. japonica (a) and A. confusa (b) wood with PVAc adhesives after normal shear strength test are as shown in Figure 4.

(a)

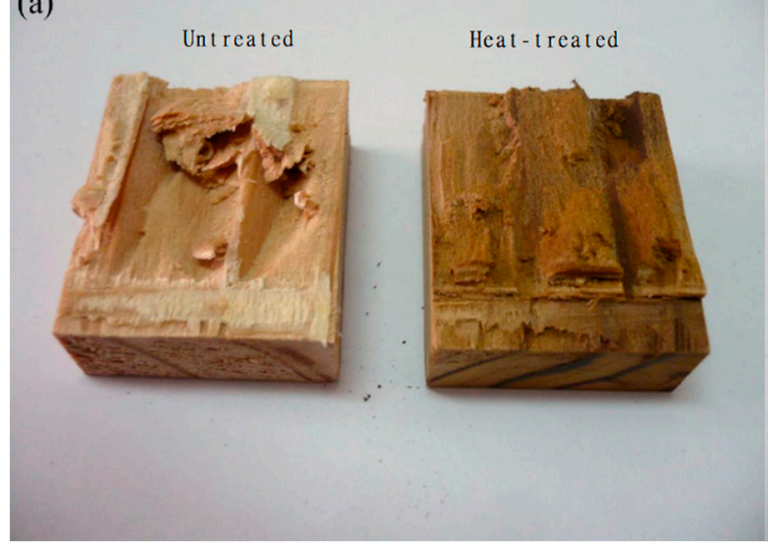

(b)

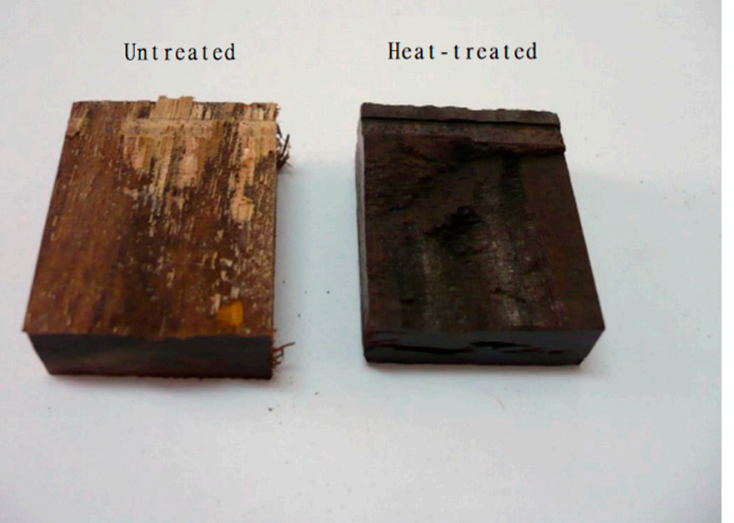

Figure 4. Appearances of untreated and heat-treated Japanese cedar (Cryptomeria japonica) (a) and Formosa acacia (Acacia confusa) (b) wood with polyvinyl acetate (PVAc) adhesive after the normal shear strength test.

\subsection{The Finishing Performances}

The appearance, adhesion and impact resistance of untreated and heat-treated $C$. japonica and A. confusa wood after PU and NC lacquer finishing are shown in Table 2, respectively. The result showed that the heated wood had a more even and darker color than the untreated wood. The adhesion of both PU and NC lacquer films of heat-treated and untreated $C$. japonica and A. confusa was grade 10, showing excellent adhesion. The striking height was the same of $10 \mathrm{~cm}$ for PU finished untreated and heat-treated C. japonica. However, it was 40 and $35 \mathrm{~cm}$ for untreated and heat-treated A. confusa, respectively, highlighting that the impact resistance of heat-treated A. confusa was slightly inferior to that of untreated wood. This may be due to the generation of a hydrophobic surface after heat treatment, resulting in a decrease of wettability for coatings. In addition, the NC lacquer finished on 
untreated or heat-treated C. japonica and A. confusa wood had the same values of $5 \mathrm{~cm}$. In summary, the adhesion and impact resistance of heat-treated wood is similar to those of untreated wood for PU and NC lacquer finishing.

Table 2. Adhesion and impact resistance of untreated and heat-treated Japanese cedar (Cryptomeria japonica) (a) and Formosa acacia (Acacia confusa) wood finished with polyurethane (PU) and nitrocellulose lacquer (NC) coatings.

\begin{tabular}{|c|c|c|c|c|c|}
\hline \multirow{2}{*}{\multicolumn{2}{|c|}{ Wood }} & \multicolumn{2}{|r|}{ PU } & \multicolumn{2}{|r|}{ NC } \\
\hline & & $\begin{array}{l}\text { Adhesion } \\
\text { (Grade) }\end{array}$ & $\begin{array}{c}\text { Impact Resistance } \\
(\mathrm{cm})\end{array}$ & $\begin{array}{l}\text { Adhesion } \\
\text { (Grade) }\end{array}$ & $\begin{array}{c}\text { Impact Resistance } \\
(\mathrm{cm})\end{array}$ \\
\hline \multirow{2}{*}{ C. japonica } & Untreated & 10 & 10 & 10 & 5 \\
\hline & Heat-treated ${ }^{1}$ & 10 & 10 & 10 & 5 \\
\hline \multirow{2}{*}{ A. confusa } & Untreated & 10 & 40 & 10 & 30 \\
\hline & Heat-treated & 10 & 35 & 10 & 30 \\
\hline
\end{tabular}

${ }^{1}$ Heat-treated conditions are heating rates of $10^{\circ} \mathrm{C} / \mathrm{h}$, temperature of $190{ }^{\circ} \mathrm{C}$, wood thickness of $50 \mathrm{~mm}$, and the holding time of $2 \mathrm{~h}$ for $C$. japonica and $3 \mathrm{~h}$ for $A$. confusa.

The hot and cold cycling test and gloss retention of untreated and heat-treated C. japonica and A. confusa woods finished with PU and NC lacquer coatings are shown in Table 3. The results indicated that all samples were intact after 20 cycles of the hot and cold cycling test. However, the gloss retention of both heat-treated woods was higher than that of the untreated woods for both PU and NC lacquer finishing. Because the dimension stability of wood could be improved after heat-treatment, the gloss lowering of film derived from wood swelling and shrinkage during the hot and cold cycling test could be reduced.

Table 3. Cycling test and gloss retention of untreated and heat-treated Japanese cedar (Cryptomeria japonica) and Formosa acacia (Acacia confusa) wood finished with polyurethane (PU) and nitrocellulose lacquer (NC) coatings.

\begin{tabular}{|c|c|c|c|c|c|}
\hline \multirow{2}{*}{\multicolumn{2}{|c|}{ Wood }} & \multicolumn{2}{|c|}{ PU } & \multicolumn{2}{|c|}{ NC } \\
\hline & & $\begin{array}{l}\text { Cycling Test } \\
\text { (Cycles) }\end{array}$ & $\begin{array}{c}\text { Gloss Retention } \\
(\%)\end{array}$ & $\begin{array}{l}\text { Cycling Test } \\
\text { (cycles) }\end{array}$ & $\begin{array}{c}\text { Gloss Retention } \\
(\%)\end{array}$ \\
\hline \multirow{2}{*}{ C. japonica } & Untreated & $>20$ & 93 & $>20$ & 93 \\
\hline & Heat-treated $^{1}$ & $>20$ & 96 & $>20$ & 100 \\
\hline \multirow{2}{*}{ A. confusa } & Untreated & $>20$ & 90 & $>20$ & 95 \\
\hline & Heat-treated & $>20$ & 100 & $>20$ & 98 \\
\hline
\end{tabular}

\footnotetext{
${ }^{1}$ Heat-treated conditions are heating rates of $10{ }^{\circ} \mathrm{C} / \mathrm{h}$, temperature of $190{ }^{\circ} \mathrm{C}$, wood thickness of $50 \mathrm{~mm}$, and holding time of $2 \mathrm{~h}$ for C. japonica and $3 \mathrm{~h}$ for $A$. confusa.
}

The lightfastness of films finished on wood was carried out on a Paint Coating Fade Meter with $100 \mathrm{~h}$ exposure; the brightness difference $\left(\Delta L^{*}\right)$, color difference $\left(\Delta E^{*}\right)$ and yellowness difference $(\Delta \mathrm{YI})$ are listed in Tables 4 and 5. The light induced degradation of wood is mainly due to the photochemical radical reactions occurring in lignin and the generation of chromophoric groups. These structures are responsible for the wood color changes. For both PU and NC lacquer finishing, the $\Delta E^{*}$ and $\Delta Y I$ values of heat-treated woods after UV-light irradiation were lower than those of untreated woods. During the heat-treatment of wood, the mainly thermal degradation occurs in hemicellulose and cellulose and the relative content of lignin increased in the heat-treated wood. The best photostability of heat-treated $C$. japonica and $A$. confusa woods' color could be partially explained by the increase of lignin stability by condensation during the heat-treatment [31]. Furthermore, the $\Delta L^{*}$ values of heat-treated wood were higher than those of untreated woods, meaning the heat-treated woods possessed a brighter surface. 
This may be due to the producing of more Stab lignin and less chromophoric groups of heat-treated wood after UV-light exposure. In addition, the $\Delta E^{*}$ and $\Delta Y I$ values of both heat-treated and untreated woods finished with PU were lower than those with NC lacquer, showing that the PU finished wood had superior lightfastness.

Table 4. Lightfastness of untreated and heat-treated Japanese cedar (Cryptomeria japonica) and Formosa acacia (Acacia confusa) wood finished with polyurethane (PU) coating.

\begin{tabular}{ccccc}
\hline \multicolumn{2}{c}{ Wood } & $\begin{array}{c}\text { Brightness } \\
\text { Difference }\left(\Delta \boldsymbol{L}^{*}\right)\end{array}$ & $\begin{array}{c}\text { Color Difference } \\
\left(\boldsymbol{\Delta} \boldsymbol{E}^{*}\right)\end{array}$ & $\begin{array}{c}\text { Yellowness } \\
\text { Difference }(\boldsymbol{\Delta} \mathbf{Y I})\end{array}$ \\
\hline \multirow{2}{*}{ C. japonica } & Untreated & $-6.17 \pm 0.19$ & $32.61 \pm 0.57$ & $15.25 \pm 0.24$ \\
\cline { 2 - 5 } & Heat-treated & $-0.47 \pm 0.97$ & $18.68 \pm 2.63$ & $3.28 \pm 0.87$ \\
\hline \multirow{2}{*}{ A. confusa } & Untreated & $-5.27 \pm 2.24$ & $11.22 \pm 2.26$ & $0.89 \pm 0.09$ \\
\cline { 2 - 5 } & Heat-treated & $-0.25 \pm 0.23$ & $1.70 \pm 0.66$ & $0.07 \pm 0.15$ \\
\hline
\end{tabular}

${ }^{1}$ Heat-treated conditions are heating rates of $10{ }^{\circ} \mathrm{C} / \mathrm{h}$, temperature of $190{ }^{\circ} \mathrm{C}$, wood thickness of $50 \mathrm{~mm}$, and the holding time of $2 \mathrm{~h}$ for $C$. japonica and $3 \mathrm{~h}$ for $A$. confusa.

Table 5. Lightfastness of untreated and heat-treated Japanese cedar (Cryptomeria japonica) and Formosa acacia (Acacia confusa) wood finished with nitrocellulose lacquer (NC) coating.

\begin{tabular}{|c|c|c|c|c|}
\hline \multicolumn{2}{|c|}{ Wood } & $\begin{array}{c}\text { Brightness } \\
\text { Difference }\left(\Delta L^{*}\right)\end{array}$ & $\begin{array}{c}\text { Color Difference } \\
\left(\Delta E^{*}\right)\end{array}$ & $\begin{array}{c}\text { Yellowness } \\
\text { Difference }(\Delta \mathrm{YI})\end{array}$ \\
\hline \multirow{2}{*}{ C. japonica } & Untreated & $-8.28 \pm 0.87$ & $63.63 \pm 1.67$ & $23.42 \pm 1.00$ \\
\hline & Heat-treated $^{1}$ & $4.56 \pm 0.63$ & $28.22 \pm 4.14$ & $4.23 \pm 0.15$ \\
\hline \multirow{2}{*}{ A. confusa } & Untreated & $-8.10 \pm 0.81$ & $11.04 \pm 0.62$ & $5.46 \pm 1.15$ \\
\hline & Heat-treated & $1.69 \pm 0.69$ & $7.98 \pm 1.29$ & $3.02 \pm 2.81$ \\
\hline
\end{tabular}

${ }^{1}$ Heat-treated conditions are heating rates of $10^{\circ} \mathrm{C} / \mathrm{h}$, temperature of $190{ }^{\circ} \mathrm{C}$, wood thickness of $50 \mathrm{~mm}$, and the holding time of $2 \mathrm{~h}$ for $C$. japonica and $3 \mathrm{~h}$ for $A$. confusa.

\subsection{Decay Resistance Performances}

The appearances of untreated and heat-treated wood after a 50-day soil block decay resistance test is shown in Figure 5. The untreated woods showed an uneven color on the surface; there were several dark spots in the untreated A. confusa. However, the heat-treated wood had a uniform color after the decay resistance test. The weight loss and color changes of untreated and heat-treated $C$. japonica and A. confusa wood after the resistance test are drawn in Figure 6. The weight loss of untreated C. japonica and A. confusa were 9.3 and $1.6 \%$, while that of the heat-treated woods were 3.0 and $0.3 \%$, respectively. In a study by Vidholdová and Reinprecht [32], 21 tropical woods were attacked intentionally for six weeks by brown-rot fungus, resulting in $0.08 \%$ to $6.48 \%$ weight loss of the wood. However, our results showed higher values (1.6\% and $9.3 \%)$. This pheromone can be explained by multiple factors in our soil block test-moisture vibration changes, water flow, temperature cycles, and microorganisms. Nonetheless, the medium difference shows that the brown-rot fungus is a key factor in the decay. The results showed that the heat-treated wood had superior decay resistance properties due to the increase of hydrophobicity and decrease of water absorbency $[17,25]$. There also was a decrease in $\mathrm{OH}$ group content, which affected enzyme recognition blocking of the fungi [33], and reduced the hemicellulose content of the wood, therefore cutting down on the main nutritive source for the fungi $[3,14,34]$. In addition, the extractives of wood and pyrolysis products such as acidic or phenolic compounds, which have fungicidal efficiency, are deposited on the wood surface, suppressing the growth of fungi $[20,27,33,35]$. The color changes on $\Delta L^{*}$ of untreated C. japonica and A. confusa were -11.3 and -15.8 after the 50 -day block decay test, meaning a darkening color was observed on the untreated wood surface; the $\Delta L^{*}$ was 4.0 and 3.5, respectively for the heat-treated wood, indicating a slight bright color obtained after the decay test. The $\Delta E^{*}$ of the untreated woods 
were 11.5 and 20.9, which was greater than the values of 5.9-0.5 from a previous study [32]. The $\Delta E^{*}$ values of heat-treated wood were also lower than that of the untreated wood. The best photostability of heat-treated wood color could be partially explained by the increase of lignin stability by condensation during the heat-treatment, restricting light from attacking the lignin. In addition, the phenol content increased after heating and the antioxidant compounds can limit degradation caused by oxygen and radicals [31].

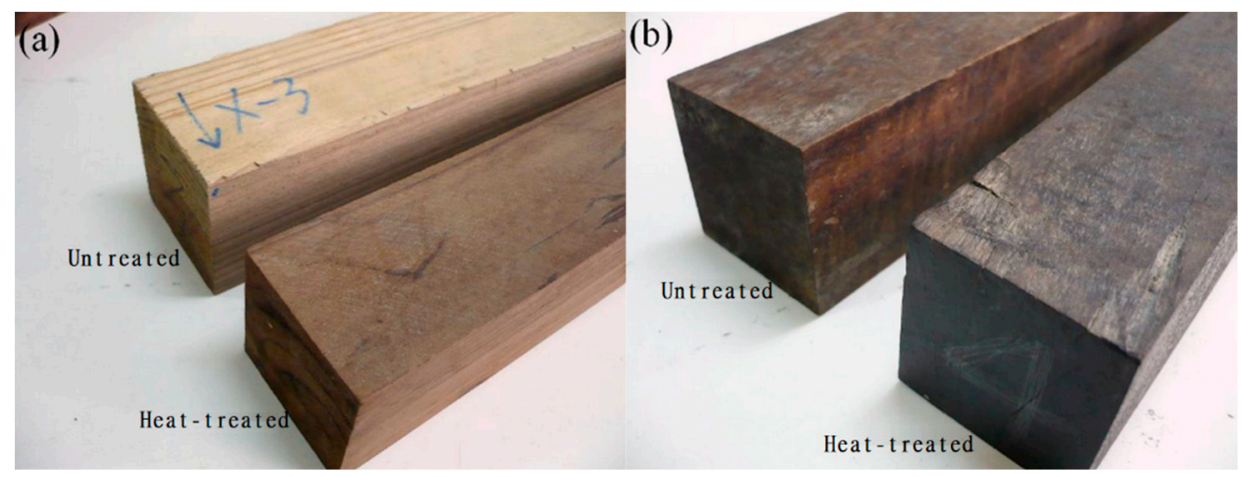

Figure 5. Appearances of untreated and heat-treated Japanese cedar (Cryptomeria japonica) (a) and Formosa acacia (Acacia confusa) (b) wood after the 50-day decay resistance test.
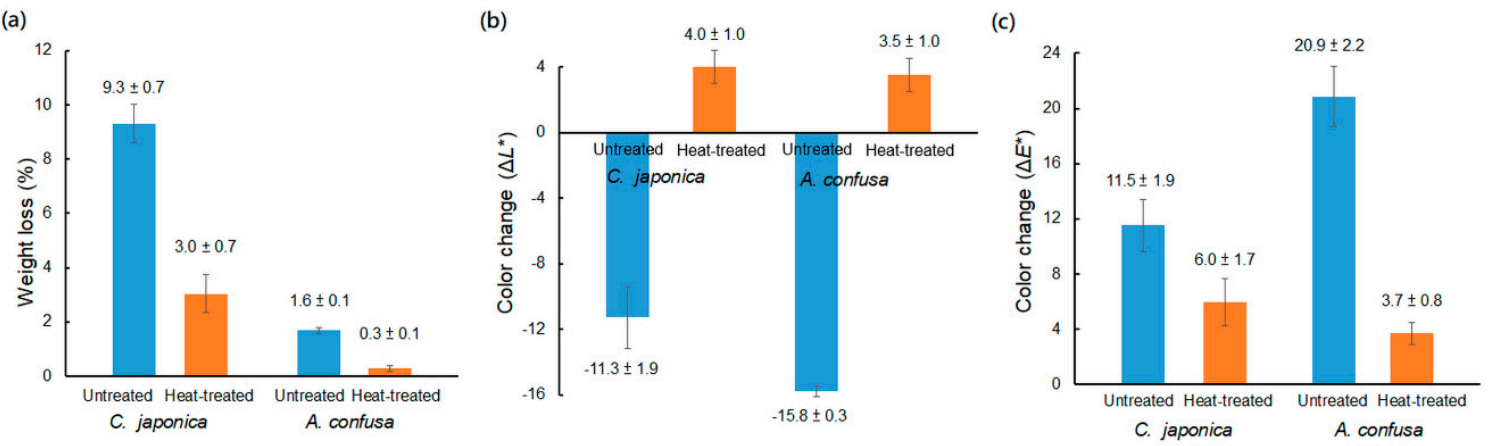

Figure 6. Weight loss (a) and color changes $(\mathbf{b}, \mathbf{c})$ of untreated and heat-treated Japanese cedar (Cryptomeria japonica) and Formosa acacia (Acacia confusa) wood after the 50-day decay resistance test.

\section{Conclusions}

The results showed that the normal shear strength of heat-treated $C$. japonica and $A$. confusa with UF and PVAc adhesives was lower than that of untreated wood (the decrease is around $99 \%$ to $72 \%$ ), but the wood failure of heat-treated wood was higher than that of the untreated one. Furthermore, the adhesion and impact resistance of heat-treated C. japonica and A. confusa finished with PU and NC coatings showed no difference with untreated wood. The finished heat-treated wood also showed superior durability and had better gloss retention and lightfastness than those of the untreated wood. The heat-treated wood also had better decay-resistance than untreated wood, ascertained by a soil block test. The weight loss of heat-treated C. japonica and A. confusa were $3.0 \%$ and $0.3 \%$, respectively. Both values of mass decrease were only $32 \%$ and $19 \%$ compared to the untreated wood.

Author Contributions: Conceptualization, C.-W.C. and K.-T.L.; methodology, W.-L.K. and C.-W.C.; formal analysis, W.-L.K., C.-W.C. and K.-T.L.; investigation, W.-L.K.; data curation, C.-W.C. and W.-L.K.; writing-original draft preparation, K.-T.L.; writing-review and editing, C.-W.C. and K.T. Lu; supervision, K.-T.L.; project administration, K.-T.L.

Funding: This research was funded by Forestry Bureau, Council of Agriculture, Executive Yuan, grant number tfbp-990506.

Conflicts of Interest: The authors declare no conflict of interest. 


\section{References}

1. Antonios, N.P.; Georgia, P. Mechanical Behaviour of Pine Wood Chemically Modified with A Homologous Series of Linear Chain Carboxylic Acid Anhydrides. Bioresour. Technol. 2010, 101, 6147-6150. [CrossRef]

2. Chang, H.T.; Chang, S.T. Modification of Wood with Isopropyl Glycidyl Ether and Its Effects on Decay Resistance and Light Stability. Bioresour. Technol. 2006, 97, 1265-1271. [CrossRef] [PubMed]

3. Shi, J.L.; Kocaefe, D.; Amburgey, T.; Zhang, J. Acomparative Study on Brown-Rot Fungus Decay and Subterranean Termite Resistance of Thermally-Modified and ACQ-C-Treatedwood. Holz. Roh. Werkst. 2007, 65, 353-358. [CrossRef]

4. Kartal, S.N.; Kakitani, T.; Imamura, Y. Bioremediation of CCA-C Treated Wood by Aspergillus Niger Fermentation. Holz. Roh. Werkst. 2004, 62, 64-68. [CrossRef]

5. Kartal, S.N.; Clausen, C.A. Leachability and Decay Resistance of Particleboard Made from Acid Extracted and Bioremediated CCA-Treated Wood. Int. Biodeterior. Biodegrad. 2001, 47, 183-191. [CrossRef]

6. Srinivas, K.; Panda, K.K. Photodegradaion of Thermally Modified Wood. J. Photochem. Photobiol. B Biol. 2012, 117, 140-145. [CrossRef]

7. Dilik, T.; Hiziroglu, S. Bonding Strength of Heated Compressed Eastern Redcedar Wood. Mater. Des. 2012, 42, 317-320. [CrossRef]

8. Korkut, S. Performance of Three Thermally Treated Tropical Wood Species Commonly Used in Turkey. Ind. Corp. Prod. 2012, 36, 355-362. [CrossRef]

9. Akyildiz, M.H.; Ates, S. Effect of Heat-Treatment on Equilibrium Moisture Content (EMC) of Some Wood Species in Turkey. Res. J. Agric. Biol. Sci. 2008, 4, 660-665. [CrossRef]

10. Del Menezzi, C.H.S.; De Souza, R.Q.; Thompson, R.M.; Teixeria, D.E.; Okino, E.Y.A.; Da Costa, A.F. Properties after Weathering and Decay Resistance of a Thermally Modified Wood Structural Board. Int. Biodeterior. Biodegrad. 2008, 62, 448-454. [CrossRef]

11. Gobakken, L.R.; Westin, M. Surface Mould Growth on Five Modified Wood Substrates Coated with Three Different Coating Systems when Exposed Outdoors. Int. Biodeterior. Biodegrad. 2008, 62, 397-402. [CrossRef]

12. Metsä-Kortelainen, S.; Antikainen, T.; Viitaniemi, P. The Water Absorption of Sapwood and Heartwood of Scots Pine and Norway Spruce Heat-Treated at $170{ }^{\circ} \mathrm{C}, 190^{\circ} \mathrm{C}, 210^{\circ} \mathrm{C}$ and $230^{\circ} \mathrm{C}$. Holz. Roh. Werkst. 2006, 64, 192-197. [CrossRef]

13. Hakkou, M.; Pétrissans, M.; Zoulalian, A.; Gérardin, P. Investigaation of Wood Wettability Changes During Heat-Treatment on The Basis of Chemical Analysis. Polym. Degrad. Stab. 2005, 89, 1-5. [CrossRef]

14. Hakkou, M.; Pétrissans, M.; Gérardin, P.; Zoulalian, A. Investigation of the Reasons for Fungal Durability of Heat-Treated Beech Wood. Polym. Degrad. Stab. 2006, 91, 393-397. [CrossRef]

15. Manninen, A.M.; Pasanen, P.; Holopainen, J.K. Comparing the VOC Emissions Between Air-Dried and Heat-Treated Scots Pine Wood. Atmos. Environ. 2002, 36, 1763-1768. [CrossRef]

16. Günduz, G.; Aydemir, D. Some Physical Properties of Heated Hornbeam (Carpinus betulus L.) Wood. Dry. Technol. 2009, 27, 714-720. [CrossRef]

17. Boonstra, M.J.; Tjeerdsma, B. Chemical Analysis of Heat Treated Softwoods. Holz. Roh. Werkst. 2006, 64, 204-211. [CrossRef]

18. Šernek, M.; Boonstra, M.; Pizzi, A.; Despres, A.; Gérardin, P. Bonding Performance of Heat-Treated Wood with Structural Adhesives. Holz. Roh. Werkst. 2008, 66, 173-180. [CrossRef]

19. Follrich, J.; Müller, U.; Gindl, W. Effects of Thermal Modification on the Adhesion Between Spruce Wood (Picea abies Karst.) and a Thermoplastic Polymer. Holz. Roh. Werkst. 2006, 64, 373-376. [CrossRef]

20. Šernek, M.; Kamke, F.A.; Glasser, W.G. Comparative Analysis of Inactivated Wood Surface. Holzforschung 2004, 58, 22-31. [CrossRef]

21. Vick, C.B. Adhesive Bonding of Wood Materials. In Wood Handbook-Wood as an Engineering Material; USDA Forest Service, Forest Products Laboratory: Madison, WI, USA, 1999; pp. 9-1-9-23. [CrossRef]

22. Shi, S.Q.; Gardner, D.J. Dynamic Adhesive Wettability of Wood. Wood Fiber Sci. 2001, 33, 58-68. [CrossRef]

23. Forestry Statistics of Taiwan Region. Available online: http://www.forest.gov.tw (accessed on 6 January 2005).

24. Kuo, W.L.; Lu, K.T. Characteristics of Cryptomeria japonica and Acacia confusa Heat-Treated Woods with Different Temperatures. Q. J. For. Res. 2012, 34, 269-286. [CrossRef]

25. Bhuiyan, M.T.R.; Sobue, N.H.N. Changes of Crystallinity in Wood Cellulose by Heat-Treatment under Dried and Moist Conditions. J. Wood Sci. 2000, 46, 431-436. [CrossRef] 
26. Follrich, J.; Teischinger, A.; Gindl, W.; Müller, U. Adhesive Bond Strength of End Grain Joints in Softwood with Varying Density. Holzforschung 2008, 62, 237-242. [CrossRef]

27. Nuopponen, M.; Vuorinen, T.; Jämsä, S.; Viitaniemi, P. The Effects of a Heat-Treatment on the Behavior of Extractives in Softwood Studied by FTIR Spectroscopic Methods. Wood Sci. Technol. 2003, 37, 109-115. [CrossRef]

28. Pizzi, A. Wood Adhesives: Chemistry and Technology; Marcel Dekker Inc.: New York, NY, USA, 1983; pp. 307-387. [CrossRef]

29. Kocaefe, D.; Poncsak, S.; Tang, J.; Bouazara, M. Effect of Heat-Treatment on the Mechanical Properties of North American Jack Pine: Thermogravimetric Study. J. Mater. Sci. 2009, 45, 681-687. [CrossRef]

30. Poncsák, S.; Shi, S.Q.; Kocaefe, D.; Miller, G. Effect of Thermal Treatment of Wood Lumbers on Their Adhesive Bond Strength and Durability. J. Adhesion Sci. Technol. 2007, 21, 745-754. [CrossRef]

31. Ayadi, N.; Lejeune, F.; Charrier, F.; Charrier, B.; Merlin, A. Color Stability of Heat-Treated Wood During Artificial Weathering. Holz. Roh. Werkst. 2003, 61, 221-226. [CrossRef]

32. Vidholdová, Z.; Reinprecht, L. The Colour of Tropical Woods Influenced by Brown Rot. Forests 2019, 10, 322. [CrossRef]

33. Hill, C.A.S. Wood Modification: Chemical, Thermal and Other Processes; John Wiley \& Sons: Chichester, UK, 2006; pp. 100-127. [CrossRef]

34. Chaouch, M.; Pétrissans, M.; Pétrissans, A.; Gérardin, P. Use of Wood Elemental Composition to Predict Heat-Treatment Intensity and Decay Resistance of Different Softwood and Hardwood Species. Polym. Degrad. Stab. 2010, 95, 2255-2259. [CrossRef]

35. Weiland, J.J.; Guyonnet, R. Study of Chemical Modifications and Fungi Degradation of Thermally Modified Wood Using DRIFT Spectroscopy. Holz. Roh. Werkst. 2003, 61, 216-220. [CrossRef]

(C) 2019 by the authors. Licensee MDPI, Basel, Switzerland. This article is an open access article distributed under the terms and conditions of the Creative Commons Attribution (CC BY) license (http://creativecommons.org/licenses/by/4.0/). 